\title{
Monoclonal antibody to cytokeratin for use in routine histopathology
}

\author{
CA MAKIN, LG BOBROW, WF BODMER \\ From the Imperial Cancer Fund, Lincoln's Inn Fields, London WC2A 3PX, and the Department of \\ Histopathology, University College Hospital Medical School, London WC1E 6JJ
}

SUMMARY CAM 5.2 is a murine monoclonal antibody, raised against the colon carcinoma cell line HT29, which recognises lower molecular weight intracellular cytokeratin proteins within secretory epithelia. Extensive indirect immunohistochemical studies have confirmed that this antibody stains formalin fixed (and freshly frozen) normal and malignant human tissue in a consistent manner. Reliable staining of conventionally processed pathological tissues provides more accurate identification and staging of human malignant epithelial diseases.

The aim of this study was to look for markers of colonic carcinoma. The most interesting monoclonal antibody raised, however, proved to be a reliable marker of epithelial tissues. Antisera and monoclonal antibodies directed against the family of cytokeratin polypeptides ranging from 70000 to 40000 daltons have a recognised place in surgical pathology. ${ }^{1-4}$ Most workers, however, have used freshly frozen tissue specimens or tissues fixed by unconventional methods due to alteration or loss of antigenic determinants by routine tissue processing.

Antibody CAM 5.2 is an IgG2a murine monoclonal immunoglobulin generated from a fusion of a mouse myeloma cell line with lymphocytes from a mouse immunised with colorectal carcinoma cells. The antibody, as characterised by immunoblotting, immunoprecipitation, and immunofluorescence, identifies the lower molecular weight cytokeratin proteins (50 000, 43000 , and 39000 daltons). Extensive assessment by immunoperoxidase on formalin fixed paraffin embedded human tissue sections shows reproducibly consistent homogeneous staining. The advantages of CAM 5.2 as opposed to other epithelial markers - for example, EMA and HMFG1 and 2-in surgical pathology and the application of this novel reagent to the immunohistochemical analysis of the "difficult" histopathological tumour are discussed.

\section{Material and methods}

CELLS, TISSUE CULTURE, AND TISSUES

HT29, a human colorectal carcinoma cell line Accepted for publication 29 May 1984 obtained from J Fogh, Sloan-Kettering Institute for Cancer Research, New York, was maintained in medium RPMI 1640 containing $10 \%$ fetal calf serum at $37^{\circ} \mathrm{C}$ in $5 \% \mathrm{CO}_{2}$ in air at $100 \%$ humidity.

SW837, SW620, and SW48, are human colorectal carcinoma cell lines originating from different tumours. ${ }^{5}$ They were maintained in Dulbecco's modification of Eagle's medium containing $10 \%$ FCS at $37^{\circ} \mathrm{C}$ in $10 \% \mathrm{CO}_{2}$ in air at $100 \%$ humidity.

LS147T, also a human colorectal carcinoma cell line, ${ }^{6}$ was maintained in Dulbecco's modification of Eagle's medium containing $10 \%$ FCS.

$\mathrm{Bu}$, a human fibroblast cell line, was maintained in RPMI 1640 containing $10 \%$ FCS. Bu was a gift from Dr S Povey, Galton Laboratory, London.

P3/NS1/1-Ag4-1 (NS1), an azaguanine resistant $\mathrm{BALB} / \mathrm{c}$ myeloma cell line, ${ }^{7}$ was maintained in RPMI 1640 containing $10 \%$ FCS and 6-thioguanine $\left(2 \times 10^{-5} \mathrm{M}\right)$.

Hybridoma CAM 5.2 was initially cultured in RPMI 1640 supplemented with $20 \%$ FCS, $10^{-4} \mathrm{M}$ hypoxanthine, $1.6 \times 10^{-5} \mathrm{M}$ thymidine, and $10^{-5} \mathrm{M}$ methotrexate (HAT). Later the hybridoma was weaned off HAT and maintained in RPMI 1640 containing $10 \%$ FCS.

Fresh human colonic carcinomas and samples of morphologically normal large bowel distant from the primary tumour were provided by Dr BC Morson, St Mark's Hospital, London. Fresh fetal tissues were supplied by Dr Ruth Nash, New Cross Hospital, London. Fixed tissue sections were supplied by Professor PG Isaacson, Department of Histopathology, University College Hospital Medical School, London, and fixed in unbuffered, $10 \%$ formol-saline 
before conventional processing and embedding in paraffin wax.

\section{IMMUNISATION AND PRODUCTION OF} HYBRIDOMAS

$\mathrm{BALB} / \mathrm{c}$ mice were immunised by an initial intraperitoneal inoculation of $2 \times 10^{6}$ live trypsinised HT 29 cells suspended in $0.2 \mathrm{ml}$ RPMI 1640 and $0.2 \mathrm{ml}$ complete Freund's adjuvant. Two months and five months later the animals were boosted with $10^{6} \mathrm{HT} 29$ cells in $0 \cdot 2 \mathrm{ml}$ RPMI 1640 intravenously.

Four days after the last injection the spleen was removed aseptically; a single cell suspension was made and fused with $10^{8}$ NS1 myeloma cells using $50 \%$ polyethyleneglycol (4000 Merck) in RPMI $1640 .^{7}$ The cells were plated out in six 96 well plates (Linbro, Flow Laboratories Ltd) with mouse spleen cells as a feeder layer overlaid with RPMI 1640 containing HAT and $20 \%$ FCS; the cells were cultured at $37^{\circ} \mathrm{C}$ in $5 \% \mathrm{CO}_{2}$ in air at $100 \%$ humidity for 14 days. Screening to identify interesting hybridomas was performed before cloning. Cloning was done by picking single cells and culturing them in individual wells of 96 well plates using mouse spleen cells as a feeder layer, in RPMI 1640, HAT, and $20 \%$ FCS at $37^{\circ} \mathrm{C}$ in $5 \% \mathrm{CO}_{2}$ in air at $100 \%$ humidity.

\section{SELECTION OF ANTIBODY PRODUCING HYBRIDS Assay system}

Initial screening was performed by indirect enzyme linked immunosorbent assay (ELISA) ${ }^{8}$ Ninety six well plates (Nunc-Immuno, Denmark) were treated with poly-l-lysine (Sigma) $0 \cdot 1 \mathrm{mg} / \mathrm{ml}$ in phosphate buffered saline (PBS) for $1 \mathrm{~h}$. All reactions were carried out at room temperature. unless otherwise stated. Confluent monolayer cultures of HT29 cells were trypsinised to obtain a single cell suspension, washed three times in PBS, and plated at a density of $10^{5}$ cells in $50 \mu \mathrm{l}$ PBS per well. To encourage adherance of cells to the base of each well, plates were centrifuged for $5 \mathrm{~min}$ at $1500 \mathrm{~g}$ and then allowed to stand for a further $10 \mathrm{~min}$. The cells were fixed with $0.025 \%$ glutaraldehyde (BDH) in PBS for $15 \mathrm{~min}$ before washing twice in PBS. Non-specific binding of monoclonal antibody to the plastic plate was reduced by filling each well with gelatin $(200$ $\mu \mathrm{g} / \mathrm{ml}$ in PBS) for at least $1 \mathrm{~h}$. If not for immediate use plates were stored at this stage at $4^{\circ} \mathrm{C}$ for up to six weeks. After two washes in PBS, endogenous peroxidase activity in the cells was blocked with $0.1 \%$ phenylhydrazine (Sigma) in PBS for $1 \mathrm{~h}$. Subsequent washes between each stage consisted of two washes with PBS and one wash with $0.2 \%$ Tween 20 in PBS. Twenty five microlitre aliquots of tissue culture supernatant were applied in duplicate for $2 \mathrm{~h}$. Next, $25 \mu$ l goat antimouse immunoglobulin diluted
$1 / 20$ in $200 \mathrm{mM}$ Tris, $\mathrm{pH} 7 \cdot 6$, with $10 \%$ normal goat serum was added for $30 \mathrm{~min}$. After this, $25 \mu \mathrm{l}$ of peroxidase-anti-peroxidase (PAP) complex diluted $1 / 100$ in $200 \mathrm{mM}$ Tris, $\mathrm{pH} 7 \cdot 6$, was added for 30 min. (Goat antimouse immunoglobulin and PAP complexes were obtained from Central Laboratories van de Bloedtransfusiedienst, Amsterdam). The reaction was visualised using $100 \mu \mathrm{l}$ volumes of 20 $\mathrm{mg}$ o-phenylenediamine (Sigma) dissolved in $10 \mathrm{ml}$ citrate buffer $(22.5 \mathrm{~g}$ disodium hydrogen orthophosphate and $5.6 \mathrm{~g}$ citric acid in 1 litre of distilled water, $\mathrm{pH} 6.0$ ) containing $5 \mu$ l hydrogen peroxide; the reaction was left to develop over $30 \mathrm{~min}$ in the dark. Absorbance was measured at $450 \mathrm{~nm}$ with a Titertek multiskan photometer.

The second screen was performed on freshly frozen tissue sections by the indirect immunoperoxidase method. ${ }^{9}$ Three millimetre cubes of fresh human colonic carcinomas and samples of morphologically normal large bowel distant from the primary tumour were snap frozen in a beaker of isopentane suspended in a freezing bath of acetone and dry ice and stored at $-70^{\circ} \mathrm{C}$ before use. Frozen sections not less than $6 \mu \mathrm{m}$ were cut on to microscope slides precoated with $0.1 \%$ poly-1-lysine and allowed to dry in air for $30 \mathrm{~min}$ at room temperature. Sections were fixed in fresh acetone for $30 \mathrm{~min}$ before washing in Tris buffered saline (TBS), $\mathrm{pH} 7 \cdot 6,(605 \mathrm{mg}$ Tris, $8 \mathrm{~g}$ $\mathrm{NaCl}$ in 1 litre of distilled water). Sections were incubated with unconcentrated monoclonal antibody supernatant for $30 \mathrm{~min}$ at room temperature in a humid chamber. After washing with TBS, sections were incubated for $30 \mathrm{~min}$ at room temperature in a humid chamber with peroxidase conjugated rabbit antimouse immunoglobulin (DAKO) diluted 1/50 in TBS. Sections were washed again in TBS and the peroxidase reaction was developed over $10 \mathrm{~min}$ using a freshly prepared, filtered solution of diaminobenzidine (Sigma, Isopac) $(6 \mathrm{mg}$ in $10 \mathrm{ml}$ of $200 \mathrm{mM}$ Tris, $\mathrm{pH} 7 \cdot 6$, containing $0.03 \%$ hydrogen peroxide). Mayer's haematoxylin was used to counterstain the sections before dehydrating and mounting in the conventional manner.

\section{Assay of supernatants}

Two weeks after the fusion, when proliferation could be detected microscopically, the unconcentrated tissue culture supernatants were screened by ELISA. Strongly positive antibodies were selected and screened on matched pairs of freshly frozen tissue sections.

\section{IMMUNODIFFUSION}

The immunoglobulin class was determined by Ouchterlony immunodiffusion ${ }^{10}$ in $1 \%$ agarose in barbitone buffer ( $12 \mathrm{~g}$ sodium barbital and $4.4 \mathrm{~g}$ barbi- 
Fig. 2 Immunoprecipitation after biosynthetic labelling with

${ }^{35}$ S-methionine. Columns 1, 3, 5, 7 with CAM 5.2; 2, 4, 6, 8 with LE61.
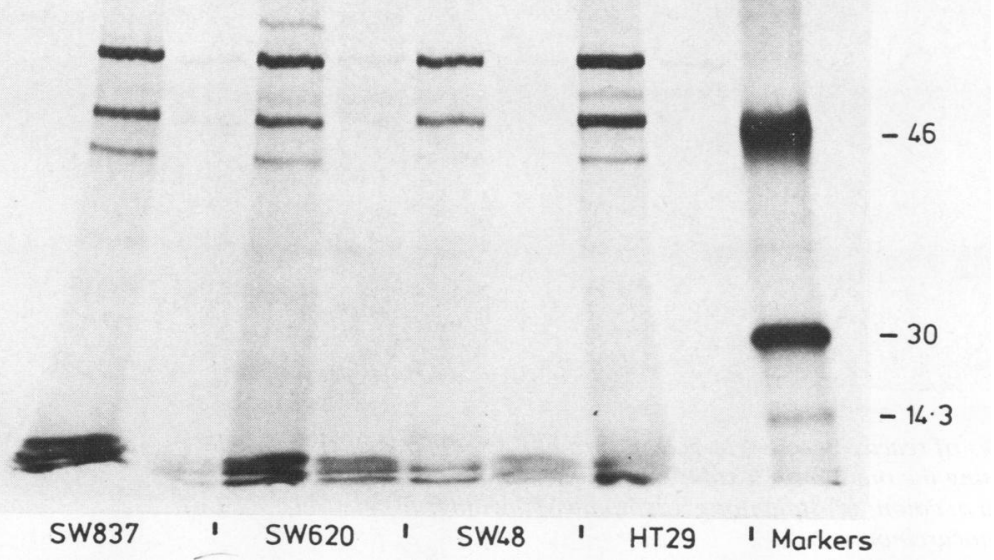

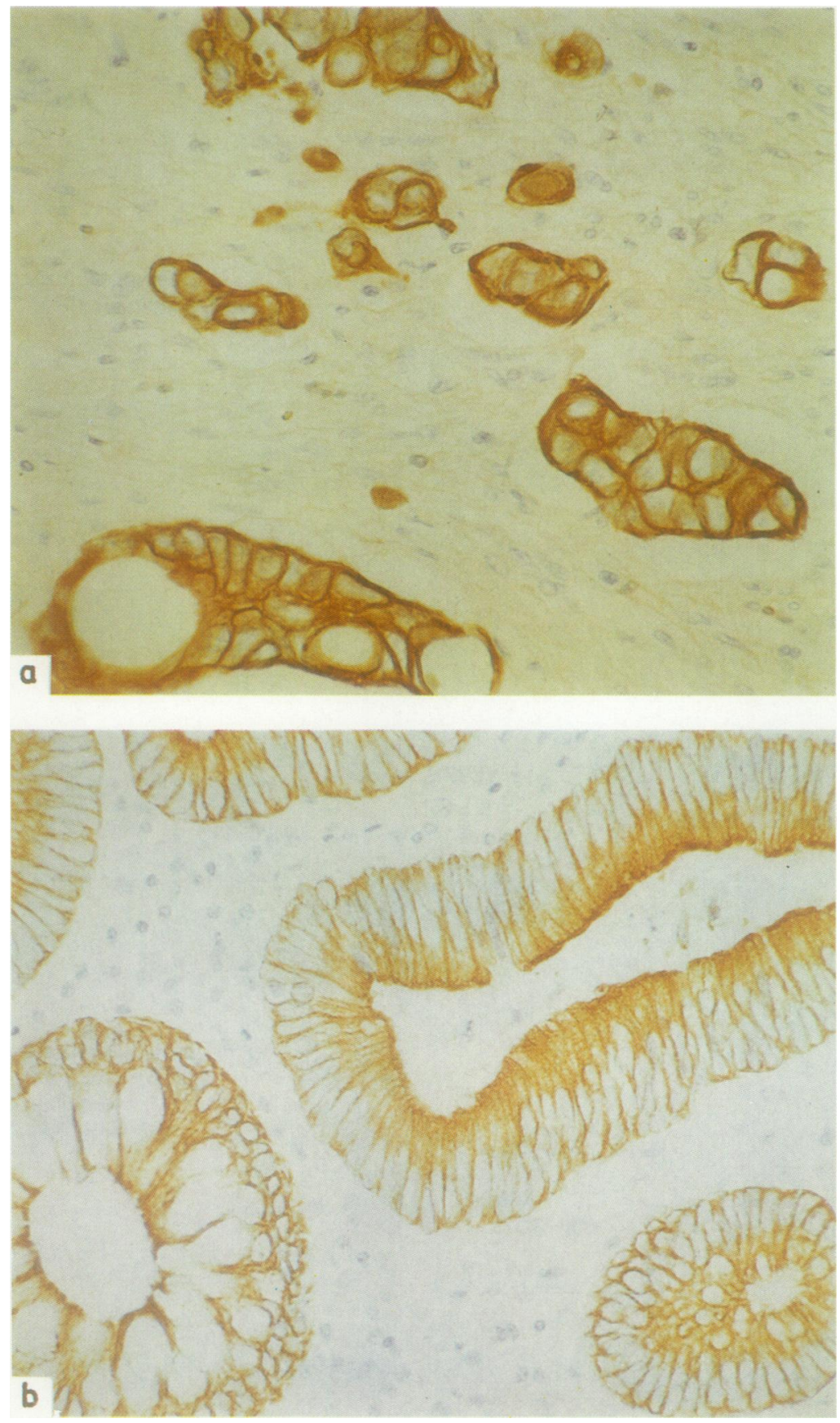

Fig. 3 Examples of reactivity of CAM 5.2 on formalin fixed paraffin embedded tissue sections using the immunoperoxidase technique. (a) colon carcinoma; (b) tubular adenoma of colon; (c) squamous carcinoma of the lung; (d) pleural effusion from breast adenocarcinoma. 

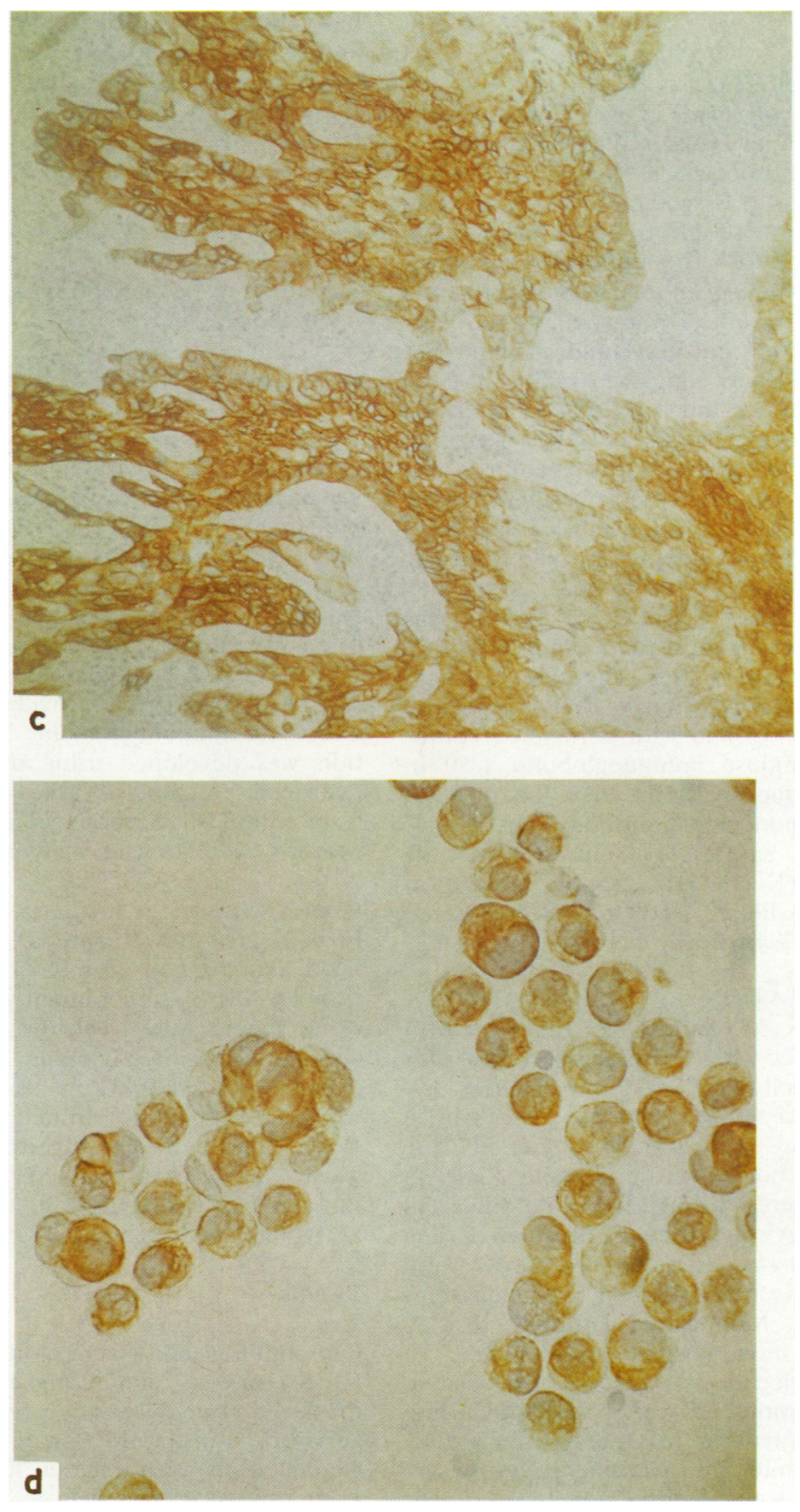
tal in 1 litre distilled water, $\mathrm{pH} 8 \cdot 2)$ using class and subclass specific rabbit antisera (Miles Laboratories, Slough).

\section{PROTEIN IMMUNOBLOTTING}

A whole cell lysate was made of each of the colorectal carcinoma cell lines HT29, SW620, SW837, and LS174T and the fibroblast cell line $\mathrm{Bu}$ in sample buffer consisting of $2 \%$ sodium dodecylsulphate (SDS), $10 \%$ glycerol, $80 \mathrm{mM}$ tris- $\mathrm{HCl}, \mathrm{pH} 6 \cdot 8$, and $100 \mathrm{mM}$ dithiothreitol. The proteins were separated by electrophoresis in one dimension on a $5-15 \%(\mathrm{wt} / \mathrm{vol})$ gradient polyacrylamide gel overlaid with a $3 \%(\mathrm{wt} / \mathrm{vol})$ polyacrylamide stacking gel. The running buffer was composed of $25 \mathrm{mM}$ tris base, $192 \mathrm{mM}$ glycine, and $0 \cdot 1 \%$ SDS. Prestained protein molecular weight markers (BRL) were run simultaneously. Transfer of the proteins on to nitrocellulose paper was performed overnight at $4^{\circ} \mathrm{C}$ using the Trans-Blot (Bio-rad) transfer apparatus and a transfer buffer comprising $25 \mathrm{mM}$ tris base, $195 \mathrm{mM}$ glycine, and $20 \%$ methanol. ${ }^{\prime \prime}$

Non-specific binding of CAM 5.2 to blot was blocked with $3 \%$ bovine serum albumin in PBS for 1 $h$ followed by washing in PBS. The blot was incubated with CAM 5.2 for $40 \mathrm{~min}$, washed in PBS, and then incubated for $30 \mathrm{~min}$ with peroxidase conjugated rabbit antimouse immunoglobulin $1 / 50$ in PBS. After a further wash in PBS the proteins identified by the monoclonal antibody were visualised using a saturated solution of 4chloro-l-naphthol (Koch-Light Laboratories Ltd) in ethanol, which was diluted 1/100 in PBS and filtered and contained $0 \cdot 1 \%$ hydrogen peroxide.

\section{IMMUNOPRECIPITATION}

Bu fibroblasts $\left(2 \times 10^{7}\right)$ and SW837 cells $\left(2 \times 10^{7}\right)$ were surface labelled with ${ }^{125} \mathrm{I}$ by lactoperoxidase for $10 \mathrm{~min}$. Labelled cells were lysed in lysis buffer $(1 \%$ Nonidet P-40, $0.5 \%$ nordeoxycholate, $1 \mathrm{mM}$ EDTA acid, $150 \mathrm{mM} \mathrm{NaCl}, 50 \mathrm{mM}$ Tris base, $\mathrm{pH} 8 \cdot 3$, $0.02 \% \mathrm{NaN}_{3}$, and bovine serum albumin $1 \mathrm{mg} / \mathrm{ml}$ ) for $30 \mathrm{~min}$ and filtered through $0.22 \mu \mathrm{m}$ Millex-GS filters (Millipore SA). Lysates were precleared using Staphylococcus aureus. Immune complexes were formed with unconcentrated CAM 5.2 supernatant overnight at $4^{\circ} \mathrm{C}$. Monoclonal antibody W6/32, which binds to monomorphic determinants of HLA-A, B, C molecules, ${ }^{12}$ was used as a positive control. Immune complexes were precipitated using Staph aureus. ${ }^{13}$ Proteins were separated on a $10 \%$ ( $w t / v o l)$ polyacrylamide slab gel using the buffer system of Laemmli, ${ }^{14}$ stained with Coomassie brilliant blue, destained, dried, and exposed to X-Omat S $x$ ray film (Kodak) at $-70{ }^{\circ} \mathrm{C}$. ${ }^{14} \mathrm{C}$-labelled molecular weight markers (Amersham International plc) were used as comparative standards.

${ }^{35}$ S-methionine (Amersham International plc) biosynthetically labelled SW837, SW620, SW48, and HT29 cells (Rudd et al, unpublished observations) were treated in a similar manner; the monoclonal antibody $\mathrm{LE} 61^{15}$ recognising cytokeratin proteins served as a positive control. Exposure was on SB-5 $x$ ray film (Kodak) at $-70^{\circ} \mathrm{C}$.

\section{IMMUNOPEROXIDASE REACTION ON FROZEN TISSUE SECTIONS}

Frozen tissue sections were cut and stained as outlined above.

IMMUNOPEROXIDASE REACTION ON FIXED.

PARAFFIN EMBEDDED TISSUES

Tissue sections were dewaxed and taken through graded alcohols to water. Endogenous peroxidase was inhibited with freshly prepared $0.5 \%$ hydrogen peroxide in methanol for $10 \mathrm{~min}$ at room temperature. The sections were digested with trypsin $(0 \cdot 1 \%$ trypsin (Sigma type II), $0 \cdot 1 \% \mathrm{CaCl}_{2}, \mathrm{pH} 7 \cdot 8$, with $\mathrm{NaOH}$ ) for $10 \mathrm{~min}$ in a humid chamber at $37^{\circ} \mathrm{C} .{ }^{16}$ The method then proceeded as for the frozen tissue sections. CAM 5.2 supernatant was applied to the sections followed by peroxidase conjugated rabbit antimouse immunoglobulin. The peroxidase reaction was developed using diaminobenzidine and hydrogen peroxide. Washes between each stage were with TBS. Sections were counterstained with Mayer's haematoxylin, dehydrated, and mounted.

\section{IMMUNOFLUORESCENCE ON FRESH TISSUE}

Frozen sections were prepared as previously outlined and fixed in acetone for $5 \mathrm{~min}$. Unconcentrated CAM 5.2 supernatant was applied for $1 \mathrm{~h}$ at room temperature. This was followed by rabbit antimouse immunoglobulin conjugated FITC (Miles), diluted $1 / 40$ in tissue culture medium, which was applied for $45 \mathrm{~min}$ at room temperature. Washes between each stage were with TBS. A final wash was given with distilled water before mounting the sections in Gelvatol 20/30 (gift of Monsanto, Springfield, Massachusetts, USA).

\section{Results}

One hundred and sixty colonies were screened by ELISA on the immunising cell line, of which 13 produced strongly positive results. Of these, eight survived transfer to larger cultures and were examined on freshly frozen human tissue sections. Four produced no reaction; three produced good generally positive staining; and one, CAM 5.2, an IgG2a immunoglobulin, was strikingly epithelial specific. 
Table 1 CAM 5.2 staining of fixed normal adult tissues

\begin{tabular}{|c|c|}
\hline Tissue type & Staining reaction \\
\hline Skeletal muscle & - \\
\hline Smooth muscle & \pm \\
\hline Cartilage & - \\
\hline Lymphoid tissues & - \\
\hline Thymus-hassals corpuscles and epithelial cells & + \\
\hline \multicolumn{2}{|l|}{ Liver } \\
\hline Most hepatocytes & - \\
\hline Few adjacent to portal tract & + \\
\hline Gall bladder and bile duct epithelium & ++ \\
\hline \multicolumn{2}{|l|}{ Skin } \\
\hline Epidermis & - \\
\hline Appendages (except sebaceous glands) & ++ \\
\hline \multicolumn{2}{|l|}{ Breast } \\
\hline Ductal epithelium & ++ \\
\hline Acinar epithelium & ++ \\
\hline Gastric epithelium & ++ \\
\hline Small bowel epithelium & ++ \\
\hline Large bowel epithelium & ++ \\
\hline Parathyroid epithelial cells & ++ \\
\hline Thyroid epithelium & ++ \\
\hline Adrenal glandular cells & - \\
\hline \multicolumn{2}{|l|}{ Lung } \\
\hline Bronchial epithelium & ++ \\
\hline Bronchial glands & ++ \\
\hline \multicolumn{2}{|l|}{ Kidney. } \\
\hline Proximal convoluted tubules & ++ \\
\hline Distal convoluted tubules & ++ \\
\hline Bowmans capsule cells & + \\
\hline Ovary epithelial cells & ++ \\
\hline Fallopian tube epithelium & ++ \\
\hline \multicolumn{2}{|l|}{ Endometrium } \\
\hline Epithelium & ++ \\
\hline Stroma & - \\
\hline \multicolumn{2}{|l|}{ Cervix } \\
\hline Endocervical glands & ++ \\
\hline Ectocervical epithelium & - \\
\hline Testis_all cells & - \\
\hline Epididymal tubules & ++ \\
\hline Rete testis & ++ \\
\hline Prostatic epithelium & ++ \\
\hline Urothelium & ++ \\
\hline \multicolumn{2}{|l|}{ Salivary glands } \\
\hline Ductal & ++ \\
\hline Acinar & ++ \\
\hline Placenta syncytio- and cytotrophoblast & ++ \\
\hline Mesothelium & ++ \\
\hline
\end{tabular}

$+=$ positive, $++=$ strongly positive, $-=$ negative .

Three major bands at 50000,43000 , and 39000 daltons were identified by the antibody on protein immunoblotting (Fig. 1), which suggested the antibody might be directed against the lower molecular weight cytokeratins and so not react with the cell surface. This was confirmed by the fact that no ${ }^{125} \mathrm{I}$ surface labelled material was precipitated by the antibody (unpublished observations) and that in preliminary studies it did not react with whole viable cells in immunofluorescence. CAM 5.2 did, however, precipitate similar bands to those seen on immunoblotting with ${ }^{35} \mathrm{~S}$-methionine labelled whole cell extracts (Fig. 2). Higher molecular weight cytokeratin polypeptides have not been identified on protein immunoblots using human foreskin keratinocytes (unpublished observations).

Immunofluorescence studies on sections of normal colon showed the characteristic filamentous,
Table 2 CAM 5.2 staining of formalin fixed tumours

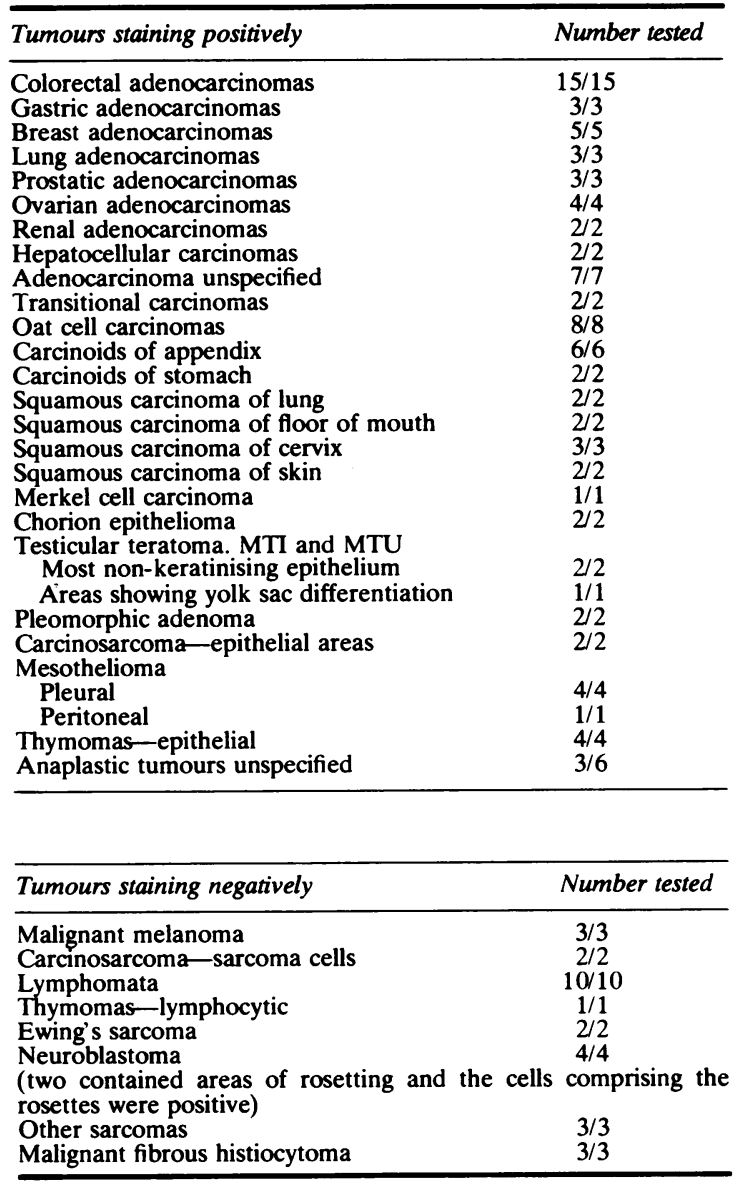

cytoplasmic distribution of cytokeratins. Unfortunately, although these intermediate filaments can be visualised under the light microscope, they do not photograph for the purpose of illustration as well as when the procedure is performed on fixed cell lines (Dr B Lane, personal communication).

The antibody reacted strongly and consistently with all epithelial tissues in preliminary tests on formalin fixed, paraffin embedded tissue sections. Trypsin digestion before the immunohistochemical reaction produced even staining comparable to that seen in freshly frozen tissue sections. In view of this (Fig. 3), the full range of reactivity was determined on normal and malignant human tissues (Tables 1 and 2) and freshly frozen fetal tissues of 20 weeks' gestation (Table 3).

CAM 5.2 stained all normal adult epithelia tested (Table 1), with the exception of stratified squamous 
Table 3 CAM 5.2 staining of fresh tissues from a fetus of 20 weeks' gestation

\begin{tabular}{|c|c|}
\hline Tissue type & Staining reaction \\
\hline Cerebellum & - \\
\hline Skeletal muscle & - \\
\hline Smooth muscle & \pm \\
\hline Cartilage & $\overline{-}$ \\
\hline Heart muscle & - \\
\hline Lymphoid tissues & - \\
\hline Liver-hepatocytes & ++ \\
\hline \multicolumn{2}{|l|}{ Skin } \\
\hline All keratinocytes & + \\
\hline Basal layer & ++ \\
\hline Appendages & ++ \\
\hline Oesophageal epithelium & ++ \\
\hline Gastric epithelium & ++ \\
\hline Small bowel epithelium & ++ \\
\hline Large bowel epithelium & ++ \\
\hline Peritoneal mesothelial cells & ++ \\
\hline Pituitary-all anterior cells & ++ \\
\hline Parathyroid gland epithelium & ++ \\
\hline Thyroid epithelium & ++ \\
\hline \multicolumn{2}{|l|}{ Pancreas } \\
\hline Ductal cells & ++ \\
\hline Exocrine epithelial & ++ \\
\hline Endocrine cells & $+t$ \\
\hline Adrenal-peripheral glandular cells & + \\
\hline \multicolumn{2}{|l|}{ Lung } \\
\hline Bronchial lining cells & ++ \\
\hline Alveolar lining cells & ++ \\
\hline \multicolumn{2}{|l|}{ Kidney } \\
\hline Proximal convoluted tubules & $+t$ \\
\hline Distal convoluted tubules & ++ \\
\hline Collecting tubules & ++ \\
\hline Bowman's capsule cells & ++ \\
\hline \multicolumn{2}{|l|}{ Ovary } \\
\hline Ductal structures in mesovarium & ++ \\
\hline $75 \%$ of sex cord cells & ++ \\
\hline
\end{tabular}

$+=$ positive,$++=$ strongly positive,$-=$ negative.

epithelia. The skin appendages reacted positively, including a single basal layer of epithelial cells towards the lower end of the hair shaft. The only exception to this were the sebaceous glands, which were negative. Despite the negative reaction on squamous epithelium, all of the squamous carcinomas, regardless of site of origin that we have studied have been positive (Table 2). Some differences were found between the results in adult and fetal tissues. Fetal hepatocytes stained uniformly positively, whereas in adults only a few hepatocytes adjacent to portal tracts stained lightly positively. In this context it is of interest to note that all the hepatomas studied were strongly positive. The other differences in reactivity between fetal and adult normal tissues were on the adrenal gland. In the fetus the cells immediately beneath the capsule were positive whereas in the adult no positive cells were noted. All carcinomas arising from neuroendocrine cells studied were positive. Mesothelium and reticular epithelia of the thymus stained positively, as did tumours arising from these tissues.

There was pale cytoplasmic staining of smooth muscle in some sections. Similar cross reactivity has been noted with HMFG1 and other cytokeratin antibodies (Dr EB Lane and Dr J TaylorPapadimitriou, personal communication).

\section{Discussion}

A monoclonal antibody, CAM 5.2, which is an IgG2a immunoglobulin, has been isolated. The antibody defines the intracellular low molecular weight cytokeratin polypeptides of about 50000 , 43000 , and 39000 daltons. On formalin fixed paraffin embedded tissue sections CAM 5.2 consistently stains normal adult epithelial cells with the exception of stratified squamous epithelia. All tumours arising from secretory epithelia and all squamous carcinomas that we have examined also stain with CAM 5.2.

Nineteen different cytokeratin polypeptides have been identified by two dimensional gel electrophoresis of intermediate filaments from different human sources; the three identified by CAM 5.2 correspond to 8,18 , and 19 in Moll's catalog. ${ }^{2}$ No epithelial tissue or cell line has been found to contain only one cytokeratin species, and the complexity of patterns varies in different epithelia. In epithelia derived from the gastrointestinal tract the cytokeratin proteins are of lower molecular weight, similar to those expressed during early embryogenesis, whereas the higher molecular weight components are found in the more complex epithelia such as the stratum corneum of the epidermis. Metastases of solid tumours retain the intermediate filament type of their primary tumour, which is of some importance when the heterogeneity of malignant cells within a single human cancer is considered. ${ }^{17}$

The non-selective staining of epithelial tumours makes CAM 5.2 a more reliable marker for differentiating carcinoma from lymphoma, melanoma, and sarcoma, and in screening effusions and bone marrows for carcinoma cells of any type (Fig. 3d), than previously described epithelial markers such as HMFG1 and $2^{1819}$ and EMA..$^{20}$ These latter markers are more selective in their epithelial reactions, and within tumours they show more heterogeneity of staining than CAM 5.2. These two attributes probably make them more useful tools for studies on individual tumour types than CAM 5.2, but their selectivity is a disadvantage in the situations already mentioned. Other monoclonal antibodies raised against the cytokeratins have not reacted reliably on formalin fixed paraffin embedded material. ${ }^{34}$

The positive reaction of CAM 5.2 with tumours of neuroendocrine origin ${ }^{22}{ }^{23}$ is an interesting observation which requires further study. This finding is in agreement with that of Ramaekers $e t a^{4}$ with their antikeratin antibody RGE53. 
The difference in staining reaction between stratified squamous epithelia and squamous carcinomas may prove useful as a prognostic indicator in premalignant and early malignant lesions arising in these tissues.

In conclusion, we emphasise the use of monoclonal antibodies, rather than conventional antisera, to intermediate filaments in routine surgical pathology. Antibodies such as CAM 5.2, which recognise different epitopes on the cytokeratin proteins and produce consistent results on formalin fixed paraffin embedded tissue, allow the clinical pathologist to distinguish with confidence anaplastic carcinomas from lymphomas, melanomas, and sarcomas. In addition, single or small numbers of epithelial cells can be easily identified in abnormal situations, such as bone marrow aspirates, cerebrospinal fluid aspirates, malignant effusions, and lymph nodes.

We thank K Miller, P Walpole, and L Soodeen for technical help; J Burchell, C Dixon and H Durbin for technical advice; B Lane for expert advice on the cytokeratin proteins; Professor PG Isaacson for encouragement; and $\mathrm{W}$ Senior for typing the manuscript. CAM would like to thank the surgeons at St Mark's Hospital, especially Mr RJ Nicholls, for their encouragement and cooperation.

\section{References}

' Gabbiani G, Kapanci Y, Barazzone P, Franke WW. Immunochemical identification of intermediate-sized filaments in human neoplastic cells. A diagnostic aid for the surgical pathologist. Am J Pathol 1981;104:206-16.

${ }^{2}$ Moll R, Franke WW, Schiller DL, Geiger B, Krepler R. The catalog of human cytokeratins: patterns of expression in normal epithelia, tumors and cultured cells. Cell 1982;31:11-24.

${ }^{3}$ Osborn M, Weber K. Biology of disease. Tumour diagnosis by intermediate filament typing: a novel tool for surgical pathology. Lab Invest 1983;48:372-94.

${ }^{4}$ Ramaekers F, Huysmans A, Moesker O, et al. Monoclonal antibody to keratin filaments, specific for glandular epithelia and their tumors. Lab Invest 1983;49:353-61.

${ }^{5}$ Leibovitz A, Stinson JC, McCombs III WB, McCoy CE, Mazur KC, Mabry ND. Classification of human colorectal adenocarcinoma cell lines. Cancer Res 1976;36:4562-9.

- Tom BH, Rutzky LP, Oyasu R, Tomita JT, Goldenberg DM, Kahan BD. Human colon adenocarcinoma cells. II. Tumorigenic and organoid expression in vivo and in vitro. $J$ Natl Cancer Inst 1977;58:1507-12.

' Kohler G, Milstein C. Derivation of specific antibody-producing tissue culture and tumor lines by cell fusion. Eur J Immunol 1976;6:511-9.

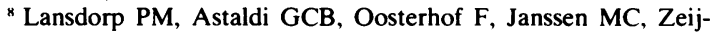
lemaker WP. Immunoperoxidase procedures to detect monoclonal antibodies against cell surface antigens. Quantitation of binding and staining of individual cells. J Immunol Methods 1980;39:393-405.

${ }^{9}$ Naiem M, Gerdes J, Abdulaziz Z, et al. The value of immunohistological screening in the production of monoclonal antibodies. J Immunol Methods 1982;50:145-60.

${ }^{10}$ Ouchterlony $\mathrm{O}$, Nilsson LA. Immunodiffusion and immunoelectrophoresis. In: Weir DM, ed. Handbook of experimental immunology, Oxford: Blackwell Scientific Publications, 1978: 19.

"Towbin H, Staehelin T, Gordon J. Electrophoretic transfer of proteins from polyacrylamide gels to nitrocellulose sheets: Procedure and some applications. Proc Natl Acad Sci USA 1979;76:4350-4.

${ }^{12}$ Barnstable CJ, Bodmer WF, Brown G, et al. Production of monoclonal antibodies to group A erythrocytes, HLA and other human cell surface antigens-new tools for genetic analysis. Cell 1978;14:9-20.

13 Jones PP. Analysis of H-2 and Ia molecules by two-dimensional gel electrophoresis. J Exp Med 1977; 14:1261-79.

${ }^{14}$ Laemmli UK. Cleavage of structural proteins during the assembly of the head of bacteriophage T4. Nature 1970;227:680-5.

is Lane EB. Monoclonal antibodies provide specific intramolecular markers for the study of epithelial tonofilament organisation. $J$ Cell Biol 1982;92:665-73.

${ }^{10}$ Mepham BL, Frater W, Mitchell BS. The use of proteolytic enzymes to improve immunoglobulin staining by the PAP technique. Histochem $J$ 1979;11:345-57.

${ }^{17}$ Brattain MG, Fine WD, Khaled FM, Thompson J, Brattain DE. Heterogeneity of malignant cells from a human colonic carcinoma. Cancer Res 1981;41:1751-6.

${ }^{18}$ Arklie J, Taylor-Papadimitriou J, Bodmer WF, Egan M, Millis R. Differentiation antigens expressed by epithelial cells in the lactating breast are also detectable in breast cancers. Int $J$ Cancer 1981;28: 23-9.

${ }^{19}$ Gatter KC, Abdolaziz Z, Beverley P, et al. The use of monoclonal antibodies for histopathological diagnosis of human malignancy. J Clin Pathol 1982;35:1253.

${ }^{20}$ Heyderman E, Steele K, Ormerod MG. A new antigen on the epithelial membrane: its immunoperoxidase localisation in normal and neoplastic tissue. J Clin Pathol 1979;32:35-9.

${ }^{21}$ Bell CE, Seetharam S. Expression of endodermally derived and neural crest-derived differentiation antigens by human lung and colon tumours. Cancer 1979;44:13-8.

${ }^{22}$ Lehto V-P, Stenman S, Miettinen M, Dahl D, Virtanen I. Expression of a neural type of intermediate filament as a distinguishing feature between oat cell carcinoma and other lung cancers. Am J Pathol 1983;110:113-8.

Requests for reprints to: Miss CA Makin, FRCS, Imperial Cancer Research Fund, P.O. Box 123, Lincoln's Inn Fields, London WC2A 3PX, England. 